\title{
Wesley's parish and the digital age?
}

\author{
Pete Phillips
}

The Revd Dr Peter Phillips directs the CODEC Research Centre in St John's College, Durham University, researching the interface of digital culture on religious practice, sacred texts and theology.

p.m.phillips@durham.ac.uk

Durham, UK

The following article was delivered as the annual lecture of the Methodist Sacramental Fellowship at the 2016 Methodist Conference in London. Beginning with the original context of John Wesley's well-known phrase, 'the world as my parish', this article explores the digital aspects of our global parish today. Putting the digital age on the agenda of the Church's mission is seen as a similar response to Wesley's decision to become 'more vile' and enter the world of field preaching. The lecture concludes by offering a fresh approach to Methodist identity magnified by aspects of digital culture, calling for the creation of digital Arminianism, digital field preaching, digital creativity and, ultimately, a digital parish. The article proposes that Methodism embrace a digital social holiness to spread scriptural holiness throughout the geographic and digital landscape.

WESLEY • DIGITAL • CULTURE • ARMINIANISM • CREATIVITY • TECHNOLOGY $\bullet$ INTERNET • EVANGELISATION 


\section{The world as my parish}

If you asked me to take a guess, I would have said Wesley's famous quote about the world being his parish would have come from the second half of his ministry, after the establishment of societies and preaching houses. Instead, it actually comes about a year after his great Aldersgate experience and only a few weeks after the beginning of his foray into field preaching at the instigation of George Whitefield in the journal entry for 11 June 1739.

If you asked me to take a guess, I would have said the quote referred to overseas missions and a link to possible American adventures. Instead, it is found in a section of the journal caught up in the flurry of charismatic responses to Wesley's preaching in Newgate, Bath, Baldwin Street, the New Room and the Bowling Green in Bristol. It is found amid the controversies that Wesley's preaching was causing especially among the higher elements of society. The passage directly prior to this passage recounts an interaction between Beau Nash - the gambling-obsessed celebrity at the centre of Bath's elite, cosmopolitan set - who had publicly rebuked Wesley for his use of conventicles (public gatherings where crowds could be addressed). Wesley rightly pointed out to Nash that the Conventicle Act was meant to put down sedition not religion.

If you asked me to take a guess, I would have said the quote was from a public address, a sermon, a speech to Oxford University, perhaps a policy discussion at some gathering of Christian leaders. Instead, Wesley makes the quote in an anonymous letter as a response to anonymous comments about his unusual ministry. In direct response to a proposal that he stop preaching in other people's parishes, Wesley points out that since he does not have a parish, such a prohibition would stop him preaching at all. Instead, he says, 'I look upon all the world as my parish.'

Scholars, of course, are not sure to whom Wesley wrote this letter. Perhaps John Clayton, perhaps James Hervey, as Goodhead argues. ${ }^{1}$ Others, including Henry Rack, suggest it could be either man. ${ }^{2}$

Both, of course, along with the great pioneer of field preaching, George Whitefield, were notable members of the Holy Club in Oxford, and perhaps it is there among those conversations that the sentiments would have fitted in best. Wesley and Whitefield had pushed the members of the Club to 'think of new and unconventional ways of conveying the gospel to the unregenerate.' ${ }^{3}$ When Whitefield decided to begin preaching in public to the miners of 
Kingswood in February 1739, he goaded Wesley to come and join the endeavour. ${ }^{4}$ And, indeed, Wesley did - choosing to become even more vile for the sake of the gospel.

Whoever Wesley's correspondent was, there seems little new in what Wesley is saying here - his colleagues in the Holy Club and field preachers throughout Scotland, Northern Ireland and Wales would have understood precisely the argument he was making and the context in which he was making it.

But what does he actually say?

11 June 1739:

You say, you cannot reconcile some parts of my behavior with the character I have long supported. No, nor ever will. Therefore I have disclaimed that character on every possible occasion. I told all in our ship, all at Savannah, all at Frederica, and that over and over, in express terms, 'I am not a Christian; I only follow after, if haply I may attain it.'

If you ask on what principle I acted, it was this: 'A desire to be a Christian; and a conviction that whatever I judge conducive thereto that I am bound to do; wherever I judge I can best answer this end, thither it is my duty to go.' On this principle I set out for America; on this I visited the Moravian church; and on the same am I ready now (God being my helper) to go to Abyssinia or China, or whithersoever it shall please God, by this conviction, to call me.

Permit me to speak plainly. If by catholic principles you mean any other than scriptural, they weigh nothing with me; I allow no other rule, whether of faith or practice, than the holy Scriptures. But on scriptural principles, I do not think it hard to justify whatever I do. God in Scripture commands me, according to my power, to instruct the ignorant, reform the wicked, confirm the virtuous. Man forbids me to do this in another's parish; that is, in effect, to do it at all, seeing I have now no parish of my own, nor probably ever shall. Whom then shall I hear, God or man?

I look upon all the world as my parish; thus far I mean, that, in whatever part of it I am, I judge it meet, right, and my bounden duty 
to declare unto all that are willing to hear, the glad tidings of salvation. This is the work which I know God has called me to; and sure I am that His blessing attends it. Great encouragement have I, therefore, to be faithful in fulfilling the work He hath given me to do. His servant I am, and, as such, am employed according to the plain direction of His Word, 'As I have opportunity, doing good unto all men'; and His providence clearly concurs with his Word; which has disengaged me from all things else, that I might singly attend on this very thing, 'and go about doing good.'

The context, despite the references to Georgia, Abyssinia and China in the opening paragraphs, is not world mission but rather the mission to the poor in Bristol - to his decision to become more vile and follow Whitefield's example. In the weeks running up to the letter, Wesley talks of preaching to almost 50,000 people in the area around Bristol and Bath - a massive number of people for the time. His journal is full of revivalist experiences, of showy conversions, and spectacular healings accompanying his ministry - and the utter contempt of the Church and some of his former colleagues. It is in this context that Wesley makes use of his status as a Fellow of Lincoln College - to preach not in a parish but to every part of the Church, not stand by parochial boundaries and the niceties of the Church but instead to transcend those boundaries to bring the gospel to whoever needed to hear it - 'to instruct the ignorant, reform the wicked and confirm the virtuous' - indeed, to ensure that those who preferred the alehouses and other places of relaxation on Sundays might still hear the good news of the gospel - publically, openly, freely.

Evidently, this was difficult territory for Wesley: 'Pressed by those on one side', as Rack points out, ${ }^{6}$ wishing to substitute their own church order for that of the Church of England and those on the other side condemning him even for his own 'irregularities', which he saw as consistent with an overall loyalty to the Church. But in this famous phrase, he takes the moral high ground - every grave or tombstone, every wall or mound, every market cross or tree stump was now a pulpit. Every moment, every gathering of people, an opportunity to preach the gospel. Wesley did indeed regard the whole world as his parish. When he makes the decision to answer the need in the Americas, this early saying becomes prescient of Methodism's global reach. 


\section{Reflecting on digital culture}

In 2009, Pope Benedict wrote a message especially directed to digital millennials - those who have grown up within a digital world. It was entitled 'New Technologies, New Relationships. Promoting a Culture of Respect, Dialogue and Friendship'. In it, Pope Benedict argues:

These technologies are truly a gift to humanity and we must endeavour to ensure that the benefits they offer are put at the service of all human individuals and communities, especially those who are most disadvantaged and vulnerable. ${ }^{7}$

He goes on to call on Catholic believers to bring their own Christian witness to the digital world - pointing to the early Church's embrace of contemporary technology for evangelisation and the need to do just the same in our own contemporary setting:

Just as, at that time, a fruitful evangelization required that careful attention be given to understanding the culture and customs of those pagan peoples so that the truth of the gospel would touch their hearts and minds, so also today, the proclamation of Christ in the world of new technologies requires a profound knowledge of this world if the technologies are to serve our mission adequately.

In Pope Francis' recent encyclical on the environment, Laudato Si', he raises a number of issues with that same technology. The two popes speak only seven years apart, but so much has happened in those seven years - from the first inklings of the power of Facebook and Twitter, to mass adoption of social media and its impact on global society. So, in a more guarded appreciation of the impact of digital culture, Pope Francis argues:

When media and the digital world become omnipresent, their influence can stop people from learning how to live wisely, to think deeply and to love generously ... True wisdom, as the fruit of selfexamination, dialogue and generous encounter between persons, is not acquired by a mere accumulation of data which eventually leads to overload and confusion, a sort of mental pollution. ${ }^{8}$ 
Real relationships with others, with all the challenges they entail, now tend to be replaced by a type of internet communication that enables us to choose or eliminate relationships at whim, thus giving rise to a new type of contrived emotion which has more to do with devices and displays than with other people and with nature.

Indeed, in his earlier encyclical Evangelii Gaudium, Francis had raised similar concerns about the impact of individualisation and consumerism in contemporary society, which can weaken 'the development and stability of personal relationships and distort family bonds'. The brunt of Pope Francis' argument in Laudato Si', though, is not the dangers of social media, but the detrimental effect on the environment and human flourishing that the growth of a purely technocratic paradigm will have. When we see the earth simply as a resource to be harvested, as raw materials for consumerist technology, then we will destroy that very earth and the humanity it nurtures. This echoes Heidegger's arguments in The Question Concerning Technology about the power of technology to turn all creation into a resource bank for its own use. ${ }^{9}$

From a secular point of view, Robert MacDougall talks of our contemporary culture in terms of Digination, drawing strongly on Marshall McLuhan's concept of the global village. ${ }^{10}$ MacDougall argues that technology has, by and large, become not just a desirable accompaniment to contemporary life but a necessary one. Without digital, he argues, we feel left out $\left(\mathrm{FOMO}^{11}\right)$, lacking, incomplete. He refers to McLuhan's discussion about the role of the car in the USA in the middle of the last century: 'Although it may be true to say that an American is a creature of four wheels ... it is also true that the car has become an article of dress without which we feel uncertain, unclad, and incomplete in the urban compound.' ${ }^{\prime 2}$ In other words, technology, increasingly so with adaptability, wearability and 'embeddability' of digital technology, has become not just an 'accepted' but an 'assumed' part of the culture we live in. There are plenty of anecdotes and studies about the way in which digital millennials, especially, see technology not as a luxury but as a necessity in today's culture. ${ }^{13}$ MacDougall notes that the pervasive use of technology in education, in the workplace, in the domestic environment and indeed throughout entertainment culture, means that humanity is not choosing to adopt technology but that it is becoming an assumed substratum to human existence. There are already parodies adding Wi-Fi connectivity to the bottom of Maslow's hierarchy of needs. We are, as Amber Case argues, already cyborgs. ${ }^{14}$ 
Benedict, Francis, MacDougall and Heidegger have other ideas about technology and media ecology - especially technology as good for humanity, as enhancement of the human identity, picking up a good deal of the conversation around the Social Shaping of Technology promoted within Heidi Campbell and Pauline Cheong's work on the interface between religious culture and technology. ${ }^{15}$ Quoting Pope John Paul II in 1981, Francis talks of science and technology (Laudato Si', \#102-103) as 'the products of a God-given human creativity', enabling men and women immersed in the material world to 'leap' into the world of beauty: 'in the beauty intended by the one who uses new technical instruments and in the contemplation of such beauty, a quantum leap occurs, resulting in a fulfillment which is uniquely human.'

Or, in Heidegger's words:

Once there was a time when the bringing-forth of the true into the beautiful was called techne. And the poiessis of the fine arts was called technē... [the arts] brought the presence of the gods, brought the dialogue of divine and human destinings, to radiance. And art was simply called technē. It was a single, manifold revealing. It was pious, promos, i.e. yielding to the holding and safe-keeping of truth. ${ }^{16}$

So, in his message for the World Day of Social Communications 2016, Pope Francis makes the point that all communication reflects the heart of the communicator. For the Christian communicator, therefore, our digital engagement should reflect God's compassion, tenderness and forgiveness for all - communication touched by God's power and filled with his mercy. Towards the end of the message, Francis talks of the digital space as a public square:

The digital world is a public square, a meeting-place where we can either encourage or demean one another, engage in a meaningful discussion or unfair attacks ... The internet can help us to be better citizens. Access to digital networks entails a responsibility for our neighbour whom we do not see but who is nonetheless real and has a dignity which must be respected. The internet can be used wisely to build a society which is healthy and open to sharing ...

... This is a gift of God, which involves a great responsibility. I like to refer to this power of communication as 'closeness'. The encounter between communication and mercy will be fruitful to the degree 
that it generates a closeness, which cares, comforts, heals, accompanies and celebrates. In a broken, fragmented and polarized world, to communicate with mercy means to help create a healthy, free and fraternal closeness between the children of God and all our brothers and sisters in the one human family. ${ }^{17}$

Clearly, then, the need to evangelise contemporary society remains (Evangelii Gaudium, \#68-70), embedding faith within contemporary culture by'sparking new processes for evangelizing culture'. Modern popes seem to echo the call of Wesley and Whitefield for new ideas on evangelising all the people, not just the few who come into a church building, for flooding the public square with the gospel, for making every wall into what Charles Wesley called 'Whitefield's Pulpit'.

\section{Digitality}

Digital is everywhere. But how do you sum it up - how do you talk about it? How do you get a goldfish to discuss the water in which it lives or the human being to discuss the essence of the air she breathes? Digital is the bringing together of interpersonal communications, advanced personal computing technology, mobile technology, data-handling technology and the gradual transformation of the military's ArpaNet into Tim Berners Lee's World Wide Web. Google's thought leaders, Eric Schmidt and Jared Cohen, talk of it as the greatest experiment in anarchy ever - a global network of 7 billion people able to access more and more information:

Hundreds of millions of people are, each minute, creating and consuming an untold amount of digital content in an online world that is not truly bound by terrestrial laws. This new capacity for free expression and free movement of information has generated the rich virtual landscape we know today. Think of all the websites you've ever visited, all the emails you've sent and the stories you've read online, all the facts you've learned and fictions you've encountered and debunked. Think of every relationship forged, every journey planned, every job found and every dream born, nurtured and implemented through this platform. Consider too what the lack of top-down control allows: the online scams, the bullying campaigns, the hate-group websites and the terrorist 
chatrooms. This is the internet, the world's largest ungoverned space. $^{18}$

If you want to see that in numbers, go to the scary Internet Stats website (http://www.internetlivestats.com), which will give you all the figures for the latest 24 hours. (When I looked there had been 116 billion emails sent that day!)

In the UK, according to government statistics, 86 per cent of adults, over 44 million people, were using the internet in $2015,{ }^{19}$ or, on an independent site, 91.6 per cent of the whole population or 59.3 million people. And 58.7 per cent in the UK are on Facebook - 38 million of us. Age matters, of course, with engagement tailing off with age:

99\% among those aged $16-34$

95\% among those aged $35-54$

$87 \%$ among those aged $55-64$

$71 \%$ among those aged $65-74$

$33 \%$ among those aged $75+$.

However, engagement with the internet is less prevalent among the disabled, with about 28 per cent of disabled people regarded as non-users. Moreover, despite the massive percentages using the internet, many of the so-called fringes are less well represented, with the lowest engagement figures in Northern Ireland, Pembrokeshire, Cornwall and Teesside. Interestingly, those levels of internet penetration are comparable to the larger European countries such as Germany (88.4 per cent), France (83.8 per cent), Spain (76.9 per cent) and Sweden (94.6 per cent). Indeed, Scandinavian countries are better connected than the UK. Other European countries are less well connected such as Poland (67.5 per cent), Italy (62 per cent), Greece (63.2 per cent) and Bulgaria (63.2 per cent).

But what do people actually do online? Research measuring the behaviour of over 73,000 people in 2015 by the Internet Advertising Bureau found that the following activities were common: ${ }^{20}$

Social media accounts

Entertainment

Games

Instant messaging

News

Email
$31 \%$ - mobile/tablet 21\%, desktop 10\%

$27 \%$ - mobile/tablet $8 \%$, desktop $19 \%$

$11 \%$ - mobile/tablet $9 \%$, desktop $2 \%$

$8 \%$ - mobile/tablet 7\%, desktop $1 \%$

$7 \%$ - mobile/tablet 5\%, desktop $2 \%$

$6 \%$ - mobile/tablet $1 \%$, desktop 5\% 
That same research found that, on average, people spend 2 hours 51 minutes online each day, at both work and at home.

Another report, from multiview.com, argues that we spend seven hours a day online and includes much more awareness of surfing activity - clicking from site to site trying to find the relevant information we need or just window shopping information. So, this report argues we spend:21

\author{
$28 \%$ surfing social media \\ $24 \%$ checking emails \\ $23 \%$ surfing content \\ $19 \%$ surfing video \\ $6 \%$ shopping online \\ $1 \%$ searching.
}

What is clear is that the entertainment number is rising rapidly with more and more access to TV on demand. Most young people no longer watch broadcast, scheduled TV. Instead, they make use of catch-up TV, Netflix, Amazon Video, Now TV and similar series. Binge-watching box sets or movies is now more and more common. Moreover, YouTube is the second largest web search engine, and YouTube and Netflix now count for over half of all internet activity at any moment, with over 150,000 hours of video being watched every minute. ${ }^{22}$

Moreover, there is nothing in these reports of the problem of online pornography, with an estimated 21.2 billion visits to one porn site alone in 2015 (Pornhub) where people consumed 4.4 billion hours of pornographic material. That's just one website - with the UK having the second largest per capita page views. ${ }^{23}$

Digital is everywhere. It's not just about smartphones, computing tech and social media. It's about Universal Credit being accessible only online; about Google Books working with academic libraries to upload vast numbers of books to help reach the so-called Singularity when all knowledge is available to support some form of machine-enabled artificial intelligence; it's about data and surveillance; it's about tracing our behaviour, our location, our likes and our connections; it's about the way that Google and Facebook know us better than we know ourselves - able already to predict when a couple will split up; able to use the data we input to relay back to us the items that would perfect our consumerist paradise. It's about MOOCS (massively open online courses) and SPOCs (small-scale private offline courses), flipped classrooms, online 
access to knowledge and libraries, and remote contact courses taking over from residential training. It's about television programmes being available when we want them rather than being scheduled; about theatre productions being distributed through cinema screens; about David Hockney drawing pictures on his iPad; about virtual reality, transhumanism and the everincreasing interest in cyborgs, robots and space.

And notice what I haven't mentioned - brands of technology, levels of computing, high definition, wearables, body adaptations, drones, Twitter, Snapchat, Huffington Post, Tinder, the internet of things, the internet of everything. Digital is all that is online, but increasingly every part of our offline presence as well. It is very hard indeed not to have an online identity nowadays, as the recent Channel 4 series Hunted made absolutely clear. As MacDougall puts it:

The introduction or removal of any means of communication tends to create reverberations throughout the entire cultural system. Despite their protestations to the contrary, I'm pretty sure late adopters and even [digital] abstainers are not exempt from the psychological, social, and cultural effects and side effects of modern communication technology. While there are certainly varying degrees of immersion - that is to say, while some of us live in the high-rise downtown district, some at the city limits, and still others out in the proverbial 'woods' - we all live in Digination today. ${ }^{24}$

\section{The digital public square}

In her Dimbleby Lecture in 2015, Martha Lane Fox talked of the possibilities for Digital Britain:

It is within our reach to leapfrog every nation in the world and become the most digital, most connected, most skilled, most informed on the planet. And I think that if we did that, it would not only be good for our economy, but it would be good for our culture, our people, our health and our happiness. ${ }^{25}$

Aware of the difficulties besetting the digital world, of the negative impressions of some leading experts and of the same gulf between private virtuous 
reflection and excessive internet consumerism that Pope Francis raised, Martha Lane Fox still looks with hope for what could be done in digital culture. She picks up the words of the late, great Aaron Swartz: IIt's not OK not to understand the Internet anymore.' As Martha Lane Fox continues: 'It doesn't matter if you're 80 or eight, if you're online once a year or once a minute, understanding where the internet came from and what it can do will help you make more sense of the world.'

I'd take this line of argument even further: saying that the digital age is not part of the agenda of the Church is as culturally insensitive to the missional prompting of the Holy Spirit as Bishop Butler telling Wesley that what he and Whitefield were doing was 'a horrid thing, a very horrid thing' and that they should 'Go hence' from Bristol.

Like Wesley, we must become more vile and enter into our own form of field preaching, our own form of evangelisation of the masses. We may already be following Wesley's example of going out into the town squares and marketplaces, but perhaps also we are being called to go out into the digital world, the digital public spaces, to engage with people who now refuse point blank to take any notice of those of us who sit in our pews and think that society will flood back to church without us first going out to make connection with them! Again, back to Pope Francis:

In fidelity to the example of the Master, it is vitally important for the Church today to go forth and preach the Gospel to all: to all places, on all occasions, without hesitation, reluctance or fear. The joy of the Gospel is for all people: no one can be excluded. ${ }^{26}$

Wesley's passion for field preaching was not fuelled by rebellion against Anglican orders, nor a pre-Communist proto-Marxian dream of transforming society into a just world. Instead, Wesley was compelled to preach the good news about Jesus; to share the good news about how Jesus offered salvation for all. Or, as Wesley put it in that letter in his journal on 11 June 1739:

If you ask on what principle I acted, it was this: 'A desire to be a Christian; and a conviction that whatever I judge conducive thereto that I am bound to do; wherever I judge I can best answer this end, thither it is my duty to go.' On this principle I set out for America; on this I visited the Moravian church; and on the same am I ready now (God being my helper) to go to Abyssinia or China, or whithersoever it shall please God, by this conviction, to call me. 
In other words, to be a Christian. To be real to our identity as followers of Christ, we are called to be, to do, to go wherever we feel that we can express that Christianity. Now, there is in this a recipe for disaster - we are hooked on the idea that God lives in church, hides among the pews, sleeps under the communion table. When I worked at Cliff, we took a bunch of students to London for an 'Evangelism through the Arts' course. I abandoned them at the door of Tate Modern and said, 'Go find God'. Half of them walked straight through Tate Modern, out the other side, across the river, and into St Paul's Cathedral. Surely, here is where you find God. Another quarter looked around a floor or two and joined their friends across the river. A few wandered off down the Thames. About 10 per cent came back talking of their fascination with the presence of God in this piece of art or in that encounter with a painting or in the conversation with fellow travellers around the gallery.

The Holy Club, especially Whitefield and Wesley, seemed to have come to an awareness that they shared with Cuthbert and Aidan and their fellow northern saints. You find God, you live out the gospel, as you walk among the people out in the world. That's where God is found. Yes, you do find God in church, in the liturgy, the worship, the devotion, the Bible study, the community of those who love him. But God, if he is truly omnipresent in the world, spends much more time in forests and art galleries, on council estates and in refugee camps, in city bars and French cafes, with the poor and the despised, the persecuted and the unloved, than he does with us in church. Surely we still believe this? Remember Matthew's story of the Temple veil torn in two from top to bottom (Matthew 27:51), that which divided God from his people, which corralled the presence of God within the Holy of Holies - that was torn asunder by the power of Jesus' love on the Cross. Too often, as the chapel doors close at the beginning of the service, we seem to want to sew the veil back up again.

\section{The digital parish}

Wesley's digital parish needs to take on some of the characteristics of his field preaching and of his ministry of both evangelisation and organisation - a mixture of sharing the good news, calling to conversion and of accountable discipleship within a worshipping community centred on the Bible. I wonder whether those are the five pillars of Methodism - evangelism, conversion, discipleship, worship and the Bible - and all of them riven through not with the individualism of the age but within social holiness, a social (community- 
centred) holiness which seeks to spread scriptural holiness throughout both the geographic and digital landscape.

Let me propose four aspects of a digital approach to working out our Methodist identity magnified by aspects of the digital culture.

\section{Digital Arminianism}

That 'all people need to be saved' has long been a central tenet of Wesleyan Christianity. We are an inclusive church - one that believes that salvation is available for everyone, not just a chosen few, but also that church and community is for all. We believe that God's call to find life in all its fullness in Christ is an opportunity for every human being to take up. We believe those five pillars of Methodism are for everyone - evangelism, conversion, discipleship, worship and the Bible - regardless of age, race, gender, sexuality, economic or political status, physical or mental health or ability.

It is important to note how the digital could help us to make much more of that. Because of the near omnipresence of the digital in our society, digital offers us a much greater audience and a much more diverse audience than we will ever have in the pulpits of our churches. Long ago, Marshall McLuhan referred to the contraction of world culture into a global village. Digital creates that reality, helping us to be both local and global at the same time. But also, it does this at an increasingly affordable cost, to include all members of our society within the discourse of the global village. The digital divide is increasingly one of choice rather than economics, with many developing nations leapfrogging Western nations in embracing what the digital offers through use of locally adapted technologies, zero Facebook, electronic banking and so on, and eschewing Western luxury approaches to technology.

Digital affirms opportunity for all to be connected together. But digital does more because it offers a voice to those without a voice. It offers a global village where all voices carry the same weight. Digital is a great form of democratic levelling, however much capitalism strives to give more and more power to the wealthy and to business interests. An optimistic view of digitality offers a view of all people having an equal say in the future of the world.

Moreover, asynchronous communication gives people time to think, to contribute at a slower pace so that conversation isn't always dominated by those present and confident to speak up, or by emotional outbursts, or by testosterone! It allows us to transcend some of the limitations of being present 
and subject to the prejudices we all too often show. It allows voices from the margins and from the global Church to speak into our conversations.

So, whether your voice has been stifled because of your age, gender, sexuality, mental health, disability, race or wealth, digital communication can offer you the opportunity to speak again. A radical digital Arminianism is both offered to all and also welcomes the contributions of all.

\section{Digital field preaching}

If Methodism is open to all, we need to get that message to everyone. Methodism has to reject our Babylonian captivity to our preaching house, chapels and churches. Methodism cannot afford to rely on an attractional model for growth any longer. Once children flocked to our Sunday schools. Our uniformed organisations and social events were packed with local residents. The Methodist chapel was the centre of so many communities. Too often now our churches are small and our congregations increasingly elderly. The faithful who gather are still faithful and wonderful and godly people. But there are too few Methodist churches that are reaching out into their local communities and making the gospel message accessible to all. Thank God there are some. But by embracing digital, we can break out of the church walls, pull down the chapel divide and reach out to all people. Through engaging with Facebook and local digital forums, by campaigning on local issues and learning what makes the community tick, we can earn a voice; by breaking out of the church and sharing good news online, we begin to field preach all over again!

Despite years of missional leadership at the very top of the Methodist Church hierarchy, despite our involvement in Fresh Expressions and VentureFX, despite our totemic celebrations of Mow Cop, Gwennap Pit, and Celebration Weekend at Cliff College, most of Methodism still seems to hold to the idea that as long as we keep the chapel open people will come to us. Of course, this works in several places. There are good, strong and open Methodist churches in many districts across the land. Our fresh expression and pioneer ministers, our missional deacons and lay workers, our pioneering congregations and local preachers have done a good deal of outstanding work to push out into the communities in which we all live. We must resource such ministry more and more.

On 24 June 1764, Wesley visited Whitehaven in Cumbria and made the following observation about the importance of going to the people: 
The want of field-preaching has been one cause of deadness here. I do not find any great increase of the work of God without it. If ever this is laid aside, I expect the whole work will gradually die away. ${ }^{27}$

But the model we still cling to by default is attractional, and, indeed, that can sometimes be seen most clearly in regard to our celebration of the sacraments - holy acts, celebrated in holy places, among holy people.

I remember going to a Cambridge college to preach. The chapel has massive bronze doors opening on to the quad.'Do you open them during the Eucharist? You know, to let everyone what you are doing?' 'No, it's a better atmosphere to keep them closed.' I'm always puzzled by that. John's Gospel, of course, doesn't have a formal institution of the Lord's Supper, although it is quite likely that John's readers were well aware of the Synoptic references and Paul's own words on the breaking of bread. Instead, John takes Jesus into the open, among a vast crowd - he takes bread, gives thanks and distributes the bread among the people - so close to the eucharistic fourfold actions of taking, blessing, breaking and giving. Indeed, in the sermon on the manna that follows later in the chapter, he talks of his own body as the bread, his own blood as the wine - the very source of the life, which he offers.

Such open air celebrations of the Eucharist were common in the Scottish, Irish and American forms of revival - Whitefield administered communion to thousands at Cambuslang. ${ }^{28}$ Wesley observed one such 'Scotch Communion' on Calton Hill but 'knew not what to do', and though he remained present 'did not admire the manner of distribution'.29 The revivalist communions are mirrored in Methodism with the development of the mass public love feasts and the reservation of communion for more formal settings. So, there are no references in Wesley's journal (that I could find) that unambiguously point to a celebration of the sacrament outside of a Christian meeting room, church or chapel. As Maddox states:

For Wesley, the chief means to [awakenment to God] was field preaching. Whenever this means was effective, he ushered the awakened person into the society where the full battery of means of grace could nourish and guide their future journey on the Way of Salvation. ${ }^{30}$

Perhaps there is a reflection here of our love affair with the attractional model - we keep the best hidden within our churches. Whitefield, Asbury and Coke 
had no such reticence to sharing the sacraments outside. The Cambuslang account talks of vast tents and tables set out; of sermons of preparation; of counselling for communicants and the giving of tokens to show they had received such preparation; of the meal set out to celebrate. In our own lifetimes, we can remember open-air celebrations, of thousands gathering at Methodist sites to share bread and wine, or in the celebration of a love feast. In my early ministry, I remember the people of Griffydam in Leicestershire talking of the crowds walking across the fields from the train station at Ashby to gather for the annual love feast there. And Celebration Weekend at Cliff will always be a treasured memory.

Surely, then, this is the time to move away from the disastrous attractional model which keeps the bronze gates closed? Isn't it time for us to see our role as looking outwards, moving outwards, going outwards into the world around us - to proclaim God's justice, love and mercy to all. Would that the Methodist Church were scandalously public with our worship! Would that we were brazenly taking the sacraments to the people - like the Archbishop of York baptising outside York Minster, or Greenbelt celebrating communion for the masses of people there. The bronze gates need to be burst asunder!

Lift up your heads, you gates;

be lifted up, you ancient doors, that the King of glory may come in.

(Psalm 24:7)

\section{Digital creativity}

Matthew Fox, one of the twentieth century's less traditional theologians, once spoke at the Nine O'Clock Service in Sheffield, arguing that revival would never come to the contemporary Church unless we re-embraced creativity, the arts and the artists. It is a wonderful thing that Methodism sees again the potential for embracing the arts - with artists like Ric Stott celebrated within the Church and with those creating our Conference worship making more and more use of their own creativity (Micky Youngson and Rachel Parkinson, Applecart Theatre, Paul Wood, Alison Tomlin and Barbara Glasson readily come to mind) and the increasing focus on worship which engages all of our senses.

One of the great reaffirmations of the twenty-first-century Church is a celebration of the creativity at the heart of the Christian community - classically demonstrated in the Messy Church movement. But too often Messy Church is 
seen as a children's thing, rather than as an opportunity to embrace creativity at the heart of all that we do. We are called to be co-creators with God, to share in his creative activity. That means Messy Church needs to be about more than glue and tissue paper! Messy Church needs to offer outlets in all sorts of areas for the glory of God: writing workshops, music composition, drama and dance, sculpture and glass-making, alongside painting and crafts. Messy Church is about seeing church as a place of creativity rather than passivity.

And that is again at the heart of the digital revolution. That revolution talks of the need for us not just to absorb the Web but to engage with and create the Web. Digital residents are people who move from being consumers to prosumers - those people who both consume the Web but also produce the Web. What a fantastic idea for the Church - that all the congregation become prosumers of worship - not just people who sit in the pew and absorb worship, but a people who engage in the very creation of the liturgy, from baking the bread for communion, to writing the words for the epiclesis, and creating icons for meditation. What an amazing vision of a Church confident enough to commission artists and art all over again - art produced not just by Christians but art for art's sake, creativity as part of God's universal gift to humanity.

\section{A digital parish!}

Peter Kerridge of Premier Radio has for a while talked about the 'bricks and clicks church' - local church communities that are brought even closer together by digitality. Peter points out that we already have the technology to stream our services to the world. Indeed, the Church of England selects different churches to stream a Sunday service each week on the Periscope App in its ChurchLive Project. ${ }^{31}$ Many other churches do the same. Broadcasting worship is nothing new - that was Web 1.0 - pumping out information to the world. Web 2.0 is about broadcasting and receiving, about true intercommunication where we listen to the Web as well as broadcast into the Web, where our audience is purposely invited to speak back!

So the advent of home broadband means that this can now be two-way - those housebound could link to services, sing along, engage with the worship, perhaps tweet in prayer requests and comments. The technology to do this is not difficult. Or the Church could offer training for those who found it too difficult.

Premier runs a fantastic service in the North East, offering free DAB radios to those who have become cut off from their home congregations. The review I 
did of the service was uplifting and heart-breaking at the same time - people reconnected not just to church but to their local communities. One man who lived shut away in his lounge with curtains closed received a radio and within weeks could be found sitting on his porch chatting with passers-by about the joys of football in the North East! Another woman shared emotionally how listening to hymns on the radio had helped her to learn how to sing the praises of God all over again.

There is much more that digital technology could offer - broadcasting services, Skype pastoral visiting, using protected non-public chatrooms like Slack to improve church communications, integration of Conference conversations with social media channels linked to churches and districts, remote communion, re-embracing and linking with the global Methodist community. Indeed, Microsoft's recent development of holoportation could allow global Methodists to port into our pulpits to enrich our ministries, or the housebound to join us in our chapels. 32

\section{Conclusion}

Wesley's assertion that he looked upon the whole world as his parish was an affirmation that the whole of his contemporary culture was a mission field. He delivered this affirmation in support of his radical step to take preaching into the wild; to become more vile and preach to the miners in Kingswood. In this paper, I have attempted to argue that we too are faced with making a radical step to leave behind the analogue present of the Church and to move into the digital future; to embrace digital technology and digital culture as the lingua franca, the common ground of contemporary culture, and thus the most appropriate place for us to engage with the world in which we live. I have called us to create a form of digital Arminianism - to include all; to go digital field preaching; to embrace digital creativity; and to develop digital parishes. In short, I have proposed that Methodism embrace a digital social holiness to spread scriptural holiness throughout the geographic and digital landscape.

In what way can we make use of the digital to create Arminian, public, open, creative communities - that form of digital community built upon communication that Pope Francis calls 'closeness', an intimate communication with our members, with our congregations, with the Methodist people, but also with our local communities, with the general public, with the world at large? 
The question is whether we can embrace the digital to relearn our calling to spread scriptural holiness throughout the land and to engage in a brave new world with our Wesleyan inheritance.

\section{Notes}

1. Goodhead 2010, p. 92.

2. Rack 2002, p. 188.

3. Smith 2014, p. 110.

4. Heitzenrater 1995, pp.102 and 112.

5. Curnock (ed.) 1938, vol. 2, pp. 216-218.

6. Rack 2002, p. 188.

7. Text available at: https://w2.vatican.va/content/benedict-xvi/en/messages/ communications/documents/hf_ben-xvi_mes_20090124_43rd-worldcommunications-day.html.

8. Laudato $\mathrm{Si}^{\prime}, \# 47$. Full text, and selected quotes as used here, available at: https:// focusoncampus.org/content/summary-of-laudato-si-pope-francis-encyclical-onthe-environment-7016a31d-a7ce-429a-bdcd-1893d8c9fe7d.

9. Martin Heidegger, The Question Concerning Technology (1977) - full text available: http://simondon.ocular-witness.com/wp-content/uploads/2008/05/question_ concerning_technology.pdf.

10. MacDougall 2012.

11. FOMO - 'fear of missing out' - an important driver in 24/7 net addiction.

12. Marshall McLuhan, cited in MacDougall 2012, p. 8.

13. With a positive spin in Laurence Scott's Four Dimensional Human (2015); with a negative spin in Sherry Turkle's Alone Together (2013) and Reclaiming Conversation (2015); and with a reflection on the wider culture of digital engagement in Douglas Thomas and John Seely Brown's New Culture of Learning (2011).

14. Amber Case's classic TED talk from all the way back in 2010: http://www.ted. com/talks/amber_case_we_are_all_cyborgs_now?language=en.

15. Campell 2005, 2010 and 2013 Digital; Cheong 2012a and 2012b.

16. Heidegger, The Question Concerning Technology (1977), p. 18: 'Einstmals hieß

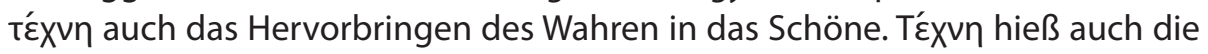
móinбıc der schönen Künste ... Sie brachten die Gegenwart der Götter, brachten die Zwiesprache des göttlichen und menschlichen Geschickes zum Leuchten.

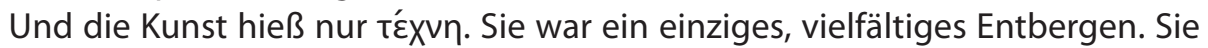
war fromm, пронос, d.h. fügsam dem Walten und Verwahren der Wahrheit. (German Text, Die Frage nach der Technik available at: https://monoskop.org/ images/2/27/Heidegger_Martin_1953_2000_Die_Frage_nach_der_Technik.pdf.)

17. Full text available from: http://www.catholicherald.co.uk/news/2016/01/25/ pope-francis-text-messages-and-social-media-are-a-gift-from-god/.

18. Schmidt and Cohen 2013, p. 3.

19. Figures taken from the ONS data on Internet Use available from: http://www.ons. 
gov.uk/businessindustryandtrade/itandinternetindustry/bulletins/internetusers/ 2015 and from http://www.worldinternetstats.com.

20. Internet Advertising Bureau Report, available online at: http://www.iabuk.net/ research/library/time-spent-online-january-june-2015.

21. https://blog.multiview.com/2016/03/02/where-does-the-time-go-what-peopledo-most-online-infographic/.

22. Intel Infographic available at: http://scoop.intel.com/files/2012/03/infographic 1080_logo.jpg. The infographic has been updated for using more recent data here: http://bit.ly/internetmin2016.

23. http://www.maxim.com/maxim-man/how-much-porn-do-people-watch-20161; for more information on porn addiction within the Christian community, see http://splash.nakedtruthproject.com.

24. MacDougall 2012, p. 1.

25. Martha Lane Fox, Dimbleby Lecture, 2015. Full text available at: http://www. bbc.co.uk/mediacentre/speeches/2015/martha-lane-fox-dot-everyone.

26. Evangelii Gaudium, \#23.

27. Curnock (ed.) 1938, vol. 5, p. 79.

28. An amazing account in John Wesley and George Whitefield in Scotland, chapter 37. Text available: https://archive.org/stream/johnwesleyandgeo00butluoft/ johnwesleyandgeo00butluoft_djvu.txt.

29. Curnock (ed.) 1938, vol. 5, p. 77.

30. Maddox 1994, p. 229.

31. For more on the ChurchLive project: https://www.churchofengland.org/mediacentre/engage-with-us-online/churchlive.aspx.

32. Microsoft's holoportation project mixes their work on the Hololens Augmented Reality Project which allows computer graphics to be superimposed on a lens through which the user looks. (For more information, see here: https://www. microsoft.com/en-us/research/project/holoportation-3/.) The normal visual field of the user is thus augmented by additional computer-generated graphics. So if the congregation were wearing augmented reality glasses, the image of a preacher could be 'ported' into the church. This technology is still in the early stages but exploration of the impact for the housebound on memory-related augmented and virtual reality is growing fast. There is some interest already in taking housebound people back to church through wearing portable headsets which provide a realistic 3D visual and aural replica of the worship environment. (For more information, see here: http://www.reminiscience.co.uk.) Moreover, development of haptic (touch) technology will mean that members of the congregation could share the peace in a fully tactile way with housebound members of the congregation.

\section{Bibliography}

Campell, Heidi. 2005. Exploring Religious Community Online. Oxford: Peter Lang. Campell, Heidi. 2010. When Religion Meets New Media. Oxford: Routledge. Campell, Heidi. 2013. Digital Religion. Oxford: Routledge. 
Cheong, Pauline. 2012a. Digital Religion, Social Media and Culture. Oxford: Peter Lang. Cheong, Pauline. 2012b. New Media and Intercultural Communication. Oxford: Peter Lang.

Curnock, Nehemiah (ed.) 1938. The Journal of the Revd John Wesley, A.M. Standard edn, London: Epworth Press.

Goodhead, Andrew. 2010. A Crown and a Cross: The Rise, Development and Decline of the Methodist Class Meeting in Eighteenth-Century England. Eugene, OR: Wipf \& Stock.

Heitzenrater, Richard. 1995. Wesley and the People Called Methodist. Nashville, TN: Abingdon Press.

MacDougall, Robert. 2012. Digination: Identity, Organization, and Public Life in the Age of Small Digital Devices and Big Digital Domains. Madison, NJ: FDUP.

Maddox, Randy. 1994. Responsible Grace. Nashville, TN: Abingdon Press.

Rack, Henry. 2002. Reasonable Enthusiast. 3rd edn, London: Epworth Press.

Schmidt, Eric and Cohen, Jared. 2013. The New Digital Age: Reshaping the Future of People, Nations and Business. London: John Murray.

Scott, Laurence. 2015. The Four-Dimensional Human. London: Heinemann.

Smith, John Howard. 2014. The First Great Awakening: Redefining Religion in British America, 1725-1775. Madison, NJ: Fairleigh Dickinson University Press.

Thomas, Douglas and Brown, John Seely. 2011. New Culture of Learning. Lexington, KY: CreateSpace.

Turkle, Sherry. 2013. Alone Together. New York: Basic Books.

Turkle, Sherry. 2015. Reclaiming Conversation. New York: Penguin. 